P-ISSN: 2615-1723

E-ISSN: 2615-1766

April 2018
Jurnal Riset Pendidikan Dasar

1 (1), ( 2018) 56-64

Submitted: Februari, Accepted: Maret, Published: April

\title{
PENGARUH KECERDASAN EMOSIONAL TERHADAP HASIL BELAJAR MATEMATIKA SISWA SEKOLAH DASAR
}

\author{
Mirnawati*, Muhammad Basri \\ Program Studi Magister Pendidikan Dasar, Pascasarjana Universitas Muhammadiyah Makassar, \\ Indonesia
}

*Korespondensi. E-mail: Mirnawati05j.pgsd@gmail.com

\begin{abstract}
Abstrak
Kecerdasan emosi terhadap pembelajaran matematika ada suatu kemampuan untuk mengendalikan emosi diri mengola dan mengekspresikan emosi terhadap orang lain, kecerdasan emosi sangat diperlukan untuk memahami pelajaran yang disampaikan oleh guru. Penelitian ini bertujuan untuk mengetahui apakahada pengaruh positif antara kecerdasan emosional terhadap hasil belajar matematikapeserta didik, dan mengubah pandangan peserta didik tentang pelajaran matematika. Penelitian ini meruapakan penelitian $e x-$ post facto. Subjek penelitian ini adalah peserta didik kelas tinggi yang berjumlah 30 peserta didik yang terdiri dari 5 peserta didik dari tiga kelas paralel. Hasil penelitian ini menunjukkan bahwa terdapat pengaruh positif antara kecerdasan emosional terhadap hasil belajar matematika. Hal ini dapat dilihat dari grafik regresi bahwa titik-titik yang tersebar mendekati garis regresi dan searah miring dengan garis regresi. Nilai koefisien determinan $\left(r^{2}\right)$ yang diperoleh sebesar 0,229 yang menandakan bahwa faktor kecerdasan emosional memberikan pengaruh terhadap hasil belajar matematika sebesar $22,9 \%$ selebihnya $77,1 \%$ dipengaruhi oleh faktor lain. Hasil analisis regresi diperoleh nilai konstan sebesar 39,993 koefisien regresi untuk vareiabel kecerdasan emosi sebesar 0,229, sehingga diperoleh persamaan regresi sederhana $\mathrm{Y}=$ $39,993+0,229 \mathrm{X}$. Berdasarkan hasil tersebut maka kesimpulan dapat diambil adalah peserta didik yang memiliki kecerdasan emosional yang tinggi akan lebih terampil dalam menenangkan diri dan memusatkan perhatian dalam memahamai materi pelajaran. Kegiatan ini sangat penting utamanya bagi guru untuk mengetahui keesulitan peserta didik. Hal ini sejalan dengan kemampuan guru untuk lebih mengenal karakter peserta didik.
\end{abstract}

Kata Kunci: kecerdasan emosional, hasil belajar matematika

\section{THE EFFECT OF EMOTIONAL INTELLIGENCE ON LEARNING RESULT OF MATHEMATICS STUDENTS BASIC SCHOOL}

\begin{abstract}
Emotional intelligence to the learning of mathematics there is an ability to control self-emotion mengola and expres: emotions to others, emotional intelligence is needed to understand the lessons conveyed by the teacher. This study aims tc determine whether there is a positive influence between emotional intelligence on mathematics learning outcomes ana students, and change the views of learners about math lessons. This research is an ex-post facto research. The subjects o, this study were high school students who numbered 30 students consisting of 5 students from three parallel classes. The results of this study indicate that there is a positive influence between emotional intelligence on mathematics learning outcomes. It can be seen from the regression graph that the dots are scattered near the regression line and in the same direction with the regression line. The value of determinant coefficient ( $r 2)$ obtained by 0.229 indicating that the emotionai intelligence factor gives effect to the learning result of mathematics equal to $22,9 \% 77,1 \%$ is influenced by other factor. Regression analysis results obtained constant value of 39.993 regression coefficient for vareiabel emotional intelligence oj 0.229 , so obtained a simple regression equation $Y=39.993+0.229 X$. Based on these results, the conclusions can be drawn are learners who have high emotional intelligence will be more skilled in calming down and focusing attention in comprehending the subject matter. This activity is very important especially for teachers to know keesulitan learners. This is in line with the ability of teachers to be more familiar with the character of learners.
\end{abstract}

Keywords: emotional intelligence, mathematics learning outcomes 


\section{PENDAHULUAN}

Paradigma baru pendidikan lebih menekankan pada peserta didik sebagai manusia yang memiliki potensi untuk belajar dan berkembang. Peserta didik harus aktif dalam pencarian dan pengembangan pengetahuan. Soedjadi (2007) mengatakan bahwa matematika sekolah adalah berkaitan dengan anak didik yang sedang menjalani proses perkembangan kognitif dan emosional, mereka memerlukan tahapan belajar yang sesuai dengan perkembangan kognitifnya.

Prihandoko (2006: 9) mengemukakan bahwa matematika berkenaan dengan strukturstruktur, hubungan-hubungan, dan konsep konsep abstrak yang dikembangkan menurut aturan yang logis. James (Ruseffendi, 1992: 27) menyatakan bahwa matematika merupakan ilmu tentang logika mengenai bentuk, susunan, besaran, dan konsep - konsep yang saling berhubungan satu sama lainnya dengan jumlah yang banyaknya terbagi ke dalam tiga bidang, yaitu aljabar, analisis, dan geometri.

Hasil belajar dipengaruhi oleh beberapa faktor yang bersifat eksternal dan internal. Faktor eksternal merupakan faktor yang berasal dari luar diri peserta didik, diantaranya adalah jenis model pembelajaran yang digunakan guru, banyaknya kegiatan perlombaan, dan perbandingan antara jam belajar efektif dengan tuntutan kurikulum yang tidak seimbang. Faktor internal merupakan faktor yang berasal dari dalam diri peserta didik, salah satunya adalah keceradasan. Syah(2013:131), menyebutkan salah satu faktor rohaniah yang dapat memengaruhi hasil belajar adalah kecerdasan. Menurut (Efendi,2005:82) kecerdasan itu terbagi atas 3 macam, yaitu Intelli-gence Quatient (IQ), Emotional Qua-tient (EQ), dan Spiritual Quatient (SQ).

(Goleman, 2015: 55) menempatkan kecerdasan interpersonal dan intrapersonal sebagai defenisi dasar tentang kecerdasan emosi. Menurutnya kecerdasan emosi adalah kemampuan individu dalam mengenali emosi diri, mengelola emosi, memotivasi diri sendiri, mengendali emosi orang lain, dan membina hubungan dengan orang lain.

Berdasarkan observasi dan wawancara dengan guru dan peserta didik pada tanggal 28 Mei 2016 SD Negeri 301 Buttu Bila. Diindikasikan bahwa peserta didik kurang dapat mengontrol dan mengola emosinya. Hal ini ditunjukkan dengan sikap peserta didik selama mengikuti proses pembelajaran. Ketika guru mnjelaskan materi matematika, banyak diantara peserta didik yang tidak memperhatikan penjelasan guru dan bahkan ada yang tertawa keras. Ketika guru memberikan tugas ada beberapa di antara peserta didik yang mengobrol dan bermain dengan teman-temannya. Selain itu, guru tersebut mengungkapkan bahwa sering didapati peserta didik yang mengejek teman sendiri hingga menangis, berkelahi di sekolah hanya karena hal-hal kecil dan berani membantah guru.

Hasil wawancara dengan guru diperoleh informasi bahwa ada beberapa peserta didik cenderung malas untuk belajar dan mengerjakan soal dalam mata pelajaran matematika. Padahal, sebenarnya peserta didik tersebut mampu untuk memahami materi pelajaran dan mengerjakan soal matematika. Hal itu terbukti ketika dibimbing oleh guru, peserta didik dapat mengerjakan. Namun, karena rasa malas peserta didik enggang mengerjakan sendiri. Peserta didik juga cenderung mudah putus asa ketika menghadapi soal matematika.

Berdasarkan hasil wawancara dengan beberapa peserta didik diperoleh keterangan bahwa banyak diantara peserta didik kurang menyukai pelajaran matematika karena menganggap matematika merupakan pelajaran yang sulit. Para peserta didik juga membutuhkan bahwa mereka cenderung 
malas untuk menghitung angka-angka dalam mata pelajaran matematika

Setiap peserta didik memiliki tingkat kecerdasan emosional yang berbeda, sehingga memengaruhi hasil belajarnya. Oleh karena itu, rumusan masalah dalam penelitian ini adalah apakah ada pengaruh kecerdasan emosional terhadap hasil belajar Matematika pada peserta didik SD Negeri 301 Buttu Bila Kecematan Lembanga Kabupaten Pinrang.

Dalam mata pelajaran matematika, kecerdasan emosi merupakan suatu hal yang diperlukan oleh peserta didik. Mustaqim (2012: 158) mengemukakan bahwa kecerdasan emosi dapat berpengaruh dalam proses dan keberhasilan belajar peserta didik. Tanpa adanya kecerdasan emosi peserta didikakan mudah menyerah, tidak memiliki motivasi untuk untuk belajar, dan tidak pandai memusatkan perhatian pada materi pelajaran, walaupun sebenarnya peserta didik tersebut mampu untuk mempelajarinya. Kecerdasan emosi yang tinggi akan melahirkan peserta didik yang berprestasi dan dapat meningkatkan hasil belajarnya.

Faktor yang mempengaruhi kecerdasan emosi yaitu faktor yang berasal dari dalam diri individu, faktor internal ini membantu individu dalam mengelola, mengontrol, dan megendalikan emosinya agar dapat terkoordinasi dengan baik dan tidak menimbulkan masalah bagi dirinya dan orang lain.

Faktor ekternal yaitu faktor yang berasal dari luar diri individu, misalnya lingkungan keluarga, masyarakat, dan media massa atau cetak. Faktor eksternal ini membantu individu untuk mengenali emosi orang lain sehingga individu dapat belajar mengenai berbagai macam emosi yang dimiliki orang lain, serta membantu individu untuk merasakan emosi orang lain dengan keadaan yang menyertainya.

Banyak contoh disekitar kita membuktikan bahwa orang memiliki kecerdasan otak saja, memiliki gelar tinggi, belum tentu sukses berkiprah di dunia pekerjaan. Seringkali justru yang berpendidikan formal yang lebih rendah , banyak yang ternyata mampu lebih berhasil. Kebanyakan program pendidikan hanya berpusat pada kecerdasan akal (IQ), padahal diperlukan pula bagaimana mengembangkan kecerdasan emosi seperti: ketangguhan, inisiatif, optimisme, kemampuan beradaptasi. Saat ini begitu banyak orang berpendidikan yang nampak begitu menjanjikan, mengalami kemandekan dalam kariernya. Lebih buruk lagi, mereka tersingkir akibat rendahnya kecerdasan emosi (Agustian, 2007). Mengungkapkan kecerdasan (intelligence) adalah kemampuan bertindak dengan menetapkan suatu tujuan, untuk berpikir secara rasional, dan untuk berhubung dengan lingkungan di sekitarnya secara memuaskan.

Sukardi ( 1988:16), kecerdasan adalah kemampuan untuk menetapkan dan mempertahankan suatu tujuan, untuk mengadakan penyesuaian dalam rangka mencapai tujuan itu dan untuk bersikap kritis terhadap diri sendiri. Kecerdasan merupakan bakat tunggal yang dipergunakan dalam situasi menyelesaikan masalah apa pun. Seseorang yang tidak bisa memecahkan masalah atau persoalan semudah-mudahnya juga memiliki inteligensi hanya tarafnya yang rendah. Oleh karena itu, kecerdasan pada hakikatnya merupakan suatu kemampuan dasar yang bersifat umum untuk memperoleh suatu kecakapan yang mengandung berbagai komponen.

Dalam makna paling harfiah, Oxford English Dictionary (Goleman, 2006: 411) mendefinisikan emosi sebagai "setiap kegiatan atau pergolakan pikiran, perasaan, nafsu, setiap keadaan mental yang hebat atau meluap-luap". Emosi dapat berupa marah, takut, sedih, bahagia, cinta, malu, dan sebagainya yang merupakan titik tolak bagi nuansa kehidupan emosional kita yang tidak habis-habisnya. 
Adapun kelompok emosi dapat dilihat pada uraian sebagai berikut. (1). Amarah: beringas, mengamuk, benci, marah besar, jengkel, kesal hati, terganggu, rasa pahit, berang, tersinggung, bermusuhan, dan barangkali paling hebat, tindak kekerasan dan kebencian patologis. (2). Kesedihan: pedih, sedih, muram, melankolis, mengasihi diri, kesepian, ditolak, putus asa, dan kalau menjadi patologis, depresi berat. (3). Rasa takut: cemas, takut, gugup, khawatir, waswas, perasaan takut sekali, khawatir, waspada, sedih, tidak tenang, ngeri, takut sekali, kecut; sebagai patologi, fobia dan panik. (4). Kenikmatan: bahagia, gembira, ringan, puas, riang, senang, terhibur, bangga, kenikmatan indrawi, takjub, rasa terpesona, rasa puas, rasa terpenuhi, kegirangan luar biasa, senang sekali, dan batas ujungnya, mania. (5). Cinta: penerimaan, persahabatan, kepercayaan, kebaikan hati, rasa dekat, bakti, hormat, kasmaran, kasih. (6). Terkejut: terkejut, terkesiap, takjub, terpana. Jengkel : hina, jijik, muak, mual, benci, tidak suka, mau muntah. (7). Malu: rasa salah, malu hati, kesal hati, sesal, hina, aib, dan hati hancur lebur.

Goleman (Triantoro Safaria dan Nofrans Eka Saputra, 2012: 13) juga mengkategorikan emosi menjai 2 kategori umum jika dilihat dari dampak yang ditimbulkan, hal itu dapat di kaitkan dengan beberapa uaraian yang telah dikemuakan tersebut, dimana emosi merupakan keadaan pada diri individu yang merujuk pada suatu perasaan, pikiran - pikiran yang khas,suatu kedaan psikologis, dan kecenderungan untuk bertindak akibat adanya situasi atau rangsangan tertentu.

Kecerdasan emosional bertumpu pada hubungan antara perasaan, watak, dan naluri moral yang mencakup pengendalian diri, semangat dan ketekunan, kemampuan menyesuaikan diri, kemampuan memecahkan masalah pribadi, mengendalikan amarah serta kemampuan untuk memotivasi diri sendiri. Terutama dalam proses pembelajaran. Dalam proses pembelajaran terjadi suatu perubahan kemampuan yang dimiliki oleh peserta didik dalam berbagai bidang, dan kemampuan itu diperoleh karena adanya usaha belajar.

Akan sangat tepat jika seseorang yang memiliki hasil belajar yang tinggi yang mampu mengungkapkan gagasan baru dalam suatu bidang juga mampu mengolah emosinya dengan baik, bersikap tegas, mudah bergaul, mampu memecahkan masalah, serta dapat berfikir dengan baik dan benar. Dalam hubungannya dengan pembelajaran, penguasaan matematika merupakan salah satu kemampuan khusus yang dimiliki seseorang dan kemampuan ini sangat menunjang dalam mempelajari bidang-bidang yang lain. Sedangkan Kecerdasan Emosional (EQ) sangat mempengaruhi semua kemampuan yang dimiliki seseorang.

Sujana (1994) bahwa: "Belajar adalah proses perubahan tingkah laku seseorang berkat adanya pengalaman". Perubahan tingkah laku akibat proses belajar akan dapat diamati dan berlaku dalam waktu relatif lama. Perubahan tingkah laku dalam waktu lama itu disertai dengan usaha dari individu itu, sehingga individu itu dari tidak mampu mengerjakan sesuatu menjadi mampu mengerjakan. Perubahan yang terjadi dari proses belajar seperti yang telah dikemukakan di atas diperoleh melalui latihan (pengalaman) bukan perubahan yang terjadi dengan sendirinya karena pertumbuhan kematangan atau karena keadaan sementara. Banyak halhal yang menyerupai belajar karena memuat unsurunsur perubahan. Namun belajar di samping memiliki perubahan juga mengarahkan kegiatan serta menuntut pemusatan perhatian. Perubahan yang terjadi jauh lebih besar karena menyangkut fungsi kejiwaan keseluruhan pribadi. Dengan kata lain, hasil proses belajar tidak hanya perubahan tingkah laku, kecakapan, melainkan juga sikap dan perhatian.

Mempelajari matematika tidak hanya berhubungan dengan bilangan-bilangan serta operasi-operasinya, melainkan matematika 


\section{Jurnal Riset Pendidikan Dasar, 1 (1), April 2018 (56-64)}

Mirnawati, Muhammad Basri

juga berkenaan dengan ide-ide, strukturstruktur dan hubungan-hubungan yang diatas secara logis sehingga matematika itu berkaitan dengan konsepkonsep yang abstrak sebagai suatu strukturstruktur dan hubunganhubungan, maka matematika memerlukan simbol-simbol untuk membantu memanipulasi aturan-aturan dengan operasi yang diterapkan. (Hudoyo, 1990) menyatakan bahwa: "Belajar matematika adalah belajar tentang konsepkonsep dan struktur-struktur matematika yang terdapat dalam materi yang dipelajari serta mencari hubungan-hubungan antara konsepkonsep dan struktur matematika itu". Sedangkan menurut Muhkal (Tajuddin, 2004) menyatakan bahwa: "Pada hakekatnya belajar matematika adalah suatu kegiatan psikologis. Yaitu mempelajari atau mengkaji berbagai hubungan-hubungan antara struktur-struktur matematika melalui manipulasi simbol-simbol sehingga diperoleh pengetahuan baru".

Dalam makna paling harfiah, Oxford

English Dictionary (Goleman, 2006) mendefiniskan emosi sebagai "setiap kegiatan atau pergolakan pikiran, perasaan, nafsu, setiap keadaan mental yang hebat atau meluap-luap". Emosi dapat berupa marah, takut, sedih, bahagia, cinta, malu, dan sebagainya yang merupakan titik tolak bagi nuansa kehidupan emosional kita yang tidak habis-habisnya. Emosi merupakan suatu kekuatan penggerak dimana nilainilai dan watak dasar seseorang dalam hidup ini tidak berakar pada IQ tetapi pada kemampuan emosional.

Nggermanto ( 2001) kecerdasan emosional (emotional intelligence) adalah kemampuan untuk mengenali perasaan kita sendiri dan perasaan orang lain, kemampuan memotivasi diri sendiri, dan kemampuan mengelola emosi dengan baik pada diri sendiri dalam hubungan dengan orang lain yaitu: Kesadaran diri terdiri dari: kesadaran emosi diri, penilaian pribadi, dan percaya diri. Pengaturan diri terdiri dari: pengendalian diri, dapat dipercaya, waspada, dan inovatif.
Motivasi terdiri dari: dorongan berprestasi, komitmen, inisiatif, dan optimis. Empati terdiri dari: memahami orang lain, pelayanan, mengembangkan orang lain, dan mengatasi keragaman. Keterampilan sosial terdiri dari: pengaruh, komunikasi, kepemimpinan, katalisator perubahan, manajemen konflik, pengikat jaringan, serta kerja tim.

Kecerdasan emosional bukan didasarkan pada kepintaran seorang anak melainkan pada suatu yang dahulu disebut "karakter" atau "karakteristik pribadi". Kecerdasan emosional dan kecerdasan intelektual berinteraksi secara dinamis, baik pada keterampilan kognitif, maupun di dunia nyata. Idealnya, seseorang dapat memiliki keduanya sebagaimana ditunjukkan oleh beberapa negarawan di dunia. Kecerdasan emosional mencakup kemampuankemampuan yang berbeda dan saling melengkapi dengan kemampuan kognitif murni yang telah lebih dulu dikenal, yaitu kecerdasan akademik/intelektual/rasional (IQ). Meskipun IQ tinggi, tetapi EQ rendah,biasanya tidak banyak membantu dalam semua aspek kehidupan. IQ dan EQ mengungkapkan aktivitas-aktivitas yang berbeda dalam otak. IQ didasarkan pada kerja neokorteks, yakni suatu lapisan yang dalam evolusi berkembang paling akhir di bagian atas otak. Adapun pusat-pusat emosi berada di bagian otak lebih dalam yang secara evolusi berkembang lebih duluan. Kerja-kerja otak pada bagian inilah yang mempengaruhi EQ. Namun demikian aktivitas pusat-pusat emosi tersebut tetap selaras dengan aktivitas kerja pusat-pusat intelektual.

EQ biasa disebut "street smart (pintar)", atau kemampuan khusus yang disebut "akal sehat". EQ terkait dengan kemampuan membaca lingkungan sosial dan menatanya kembali. Juga terkait dengan kemampuan memahami secara spontan apa yang diinginkan dan dibutuhkan orang lain, demikian juga kelebihan dan kekurangan kemampuan membaca mereka, kemampuan 
untuk menjadi orang yang meyenangkan sehingga kehadirannya didambakan orang lain. Oleh karena itu, semakin tinggi EQ seseorang, semakin besar kemungkinan untuk sukses sebagai pekerja, orang tua, manager, pelajar, dan sebagainya.

\section{METODE}

Penelitian ini dilaksanakan di SD Negeri 301 Buttu Bila Kecamatan Lembang Kabupaten Pinrang tahun 2016.

Upaya menjelaskan pola hubungan fungsional antar variabel dalam penelitian ini menggunakan metode survei korelasional yang bersifat ex post facto dengan pendekatan kuantitatif dan dianalisis menggunakan analisis regresi sederhana.

Populasi penelitian ini adalah kelas tinggi sekolah dasar negeri yang berada di desa Buttu Bila Kecamatan Lembang yang berjumlah 30 SD. Sampel yang diambil dari populasi yang ada, yaitu $15 \%$ dari jumlah keseluruhan yaitu 132 peserta didik. Pengambilan sampel dilakukan dengan teknik cluster random sampling (areasampling).

Penelitian ini menggunakan dua macam data,yaitu kecerdasan emosional dan hasil belajar Matematika. Kecerdasan emosional dijaring menggunakan teknik angket, sedangkan hasil belajar Matematika dijaring dengan teknik tes.

Uji coba dilaksanakan guna mengetahui validitas, reliabilitas, dan daya beda instrumen. Instrumen yang memenuhi syarat dapat digunakan dan instrumen yang tidak memenuhi syarat harus dihapus. Perskoran kecerdasan emosional ditunjukkan pada Tabel 1.

Instrument yang digunakan dalam penelitian ini berupa skala psikologi. Skala psikologi dalam penelitian ini berupa skala kecerdasan emosi. Instrument yang digunakan diambil dari instrument Rafika Dewi Satriani yang telah divalidasi.

Table 1 Pedoman Penskoran

\begin{tabular}{ccccc}
\hline Standar penyekoran/penelitian & Selalu & Sering & $\begin{array}{c}\text { Kadang- } \\
\text { kadang }\end{array}$ & $\begin{array}{c}\text { Tidak } \\
\text { pernah }\end{array}$ \\
\hline Pernyataan favorable & 4 & 3 & 2 & 1 \\
Pernyataan unfavorable & 1 & 2 & 3 & 4 \\
\hline
\end{tabular}

Skor alternatif jawaban skala kecerdasan emosi menggunakan skala Likert. Jawaban setiap item instrument yang menggunakan skala Likert mempunyai gradasi dari sangat positif sampai sangat negatif (Sugiyono, 2013: 93).

Untuk setiap pernyataan favorable denngan alternatif jawaban selalu mendapatkan skor 4 (sangat baik), jawaban sering mendapatkan skor 3 (baik), jawaban kadang-kadang mendapatkan skor 2 (cukup), dan jawaban tidak pernah mendapatkan skor 1 (kurang). Sedangkan untuk pernyataan unfavorable dengan alternatif jawaban selalu mendapatkan skor 1 (sangat baik), jawaban sering mendapatkan skor 2 (baik), jawaban kadang-kadang mendapatkan skor 3 (cukup), dan jawaban tidak pernah mendapatka skor 4 (kurang).

Teknik pngumpulan data yang digunakan skala psiologi dan dokumentasi. Data yang diungkap oleh skala psikologi adalah deskripsi mengenai aspek kepribadian individu, motivasi, tingkat kecemasan, dan variabel kepribadian lain. Pengumpulan data dengan dokumentasi dalam penelitian ini dimaksudkan untuk mendapatkan data tentang hasil belajar matematika peserta didik dalam kurun waktu satu semester yang tercantum dalam buku rapor semester yang tercantum dalam buku rapor semester II tahun ajaran 2015/2016.

Penelitian ini menggunakan teknik statistik karena data yang diambil merupakan 
data kuantitatif, sedangkan analisis yang digunakan adalah teknik analisis regresi sederhana. Sebelum melakukan analisis data maka terlebih dahulu dilakukan uji prasyarat analisis yang meliputi ujinormalitas dan uji linieritas.

Penelitian ini akan dianalisis dengan statistik deskriptif, karena penelitian yang dilakukan adalah penelitian populasi (tanpa diambil sampelnya). Dalam statistik deskriptif juga dapat mencari kuatnya hubungan antar variabel melalui analisis korelasi dan melakukan prediksi dengan analisis regresi (Sugiyono,2008:148). Statistic dskriptif meiputi; (1) skala pengukuran, (2) menyusun data penelitian, (3) ukuran kecenderungan memusat: mean, ,median, modus, (4) ukuran keragaman: rentangan, varians, dan standar deviasi.

\section{HASIL DAN PEMBAHASAN}

Hasil analisis statistik deskriptif yang berhubungan dengan skor variabel kecerdasan emosional peserta didik disajikan pada Tabel 2.

Tabel 2. Kemampuan Kecerdasan Emosional

\begin{tabular}{cc}
\hline Statistik & Nilai Statistik \\
\hline Ukuran sampel & $\mathbf{1 3 2}$ \\
Skor ideal & $\mathbf{7 5}$ \\
Skor tinggi & $\mathbf{9 2}$ \\
Skor rendah & $\mathbf{6 0}$ \\
Rentang skor (range) & $\mathbf{3 2}$ \\
Skor rata-rata & $\mathbf{7 8 , 7 0}$ \\
Deviasi & $\mathbf{8}$ \\
Varians & $\mathbf{6 5 , 1 5}$ \\
\hline
\end{tabular}

Hasil analisis deskriptif pada variabel kecerdasan emosi, diketahui bahwa sebagian besar peserta didik SD Negeri 301 Buttu Bila memiliki tingkat kecerdasan emosi yang sedang. Dari 30 peserta didik dari 3 kelas paralel yang masing-masing 5 diantaranya di jadikan sampel, sebanyak 5 peserta didik $(16,67 \%)$ tergolong dalam kategori tinggi.Peserta didik yang memiliki kecerdasan emosi yang tinggi mampu memusatkan perhatian dalam memahami materi pelajaran, memotivasi diri sendiri untuk terus maju, optimis dalam mengahadapi kesullitan, memiliki hubungan dan persahabatan yang baik dengan orang lain, cakap memahami orang, dan memiliki hasil belajar yang baik.Sebanyak 23 peserta didik (76,67\%) tergolong dalam kategori sedang. Peserta didik yang memiliki kecerdasan emosi yang sedang akan cukup mampu memusatkan perhatian dalam memahami materi pelajaran, memotivasi diri sendri untuk terus maju, cukup optimis dalam menghadapi kesulitan, memiliki hubungan dan persahabatan yang cukup baik dengan orang lain, cukup dapat memahami orang, dan memiliki hubungan dan persahabatan yang cukup baik dengan orang lain, cukup dapat memahami orang, dan memiliki hasil belajar yang cukup baik. Selebihnya, 2 peserta didik $(6,66 \%)$ tergolong dalam kategori rendah.Peserta didik yanng memiliki kecerdasan emosi yang rendah akan sulit memusatkan perhatian dalam memahami materi pelajaran.

Hasil analisis distribusi frekuensi dan persentase yang berhubungan dengan skor variabel hasil belajar peserta didik disajikan pada Tabel 3.

Tabel 3. Kemampuan Kecerdasan Emosional

\begin{tabular}{cc}
\hline Statistik & Nilai Statistik \\
\hline Ukuran sampel & $\mathbf{1 3 2}$ \\
Skor ideal & $\mathbf{7 5}$ \\
Skor tinggi & $\mathbf{9 2}$ \\
Skor rendah & $\mathbf{6 0}$ \\
Rentang skor (range) & $\mathbf{3 2}$ \\
Skor rata-rata & $\mathbf{7 7 , 1 3}$ \\
Deviasi & $\mathbf{8 , 1 7}$ \\
Varians & $\mathbf{6 6 , 3 7}$ \\
\hline
\end{tabular}

Tidak berbada jauh dengan variabel kecerdasan kecerdasan emosi, hasil analisis deskriptik pada variabel hasil belajar matematika SD Negeri 301 Buttu Bila memiliki tingkat hasil belajar matematika yang sedang. Dari 30 peserta didik, masingmasing 5 dijadikan sampel dari kelas parallel terdapat 6 peserta didik $(20,00 \%)$ yang tergolong dalam kategori tinggi. 21 peserta didik $(70,00 \%)$ tergolong dalam kategori sedang, dan 3 peserta didik (10,00\%) yang tergolong dalam kategori rendah. 
Uji normalitas digunakan untuk menentukan apakah data berdistribusi normal atau tidak. Ujinormalitas menggunakan uji Lilliefors. Penghitungan ini dilakukan dengan asumsi jika $\mathrm{L}_{\mathrm{O}}$ lebih kecil dari $\mathrm{L}$ tabel $\left(\mathrm{L}_{\mathrm{O}}\right.$ $<$ Ltabel), maka data berasal dari populasiyang berdistribusi normal dengan taraf signifikansi $5 \%$.

Pengujian hipotesis dilakukan dengan menggunakan regresi linear sederhana dengan bantuan software statistik SPSS versi 20.0. Berdasarkan hasil perhitungan, diperoleh koofesian korelasi sebesar 0,479 sehingga koefisien determinasinya $\left(r^{2}\right)$ sebesar 0,229

Analis data di atas menunjukkan bahwa penelitian ini memperoleh nilai konstan sebesar 39,993, bararti jika nilai kecerdasan emosi peserta didik 0 , maka nilai hasil belajar matematika peserta didik adalah 39,993. Koefisien regresi untuk variabel kecerdasan emosi adalah 0,484 yang berarti setiap kenaikan 1 unit skor kecerdasan emosi maka akan diikuti kenaikan hasil belajar matematika sebesar 0,484, sehingga diperoleh persamaan regresi sederhana $\mathrm{Y}=39,993+0,484 \mathrm{X}$.

Hipotesis penelitian diterima, yang berarti bahwa terdapat pengaruh yang positif antara emosi terhadap hasil belajar matematika peserta didik SD Negeri 301 Buttu Bila. Hasil ini memiliki arti bahwa semakin tinggi tingkat kecerdasan emosi maka akan semakin tinggi pula hasil belajar matematika yang diperoleh peserta didik. Sebaliknya, semakin rendah tingkat kecerdasan emosi maka akan semakin rendah pula hasil belajar matematika yang diperoleh peserta didik.

Hasil perhitungan analisis regresi linear sederhana diperoleh nilai konstan sebesar 39,993. Koefisien regresi untuk variabel kecerdasan emosi sebesar 0,484. Sehingga diperoleh persamaan regresi sederhana $\mathrm{Y}=39,993+$ $0,484 X$. koefisien determinasi yang diperoleh sebesar 0,229 yang menandakan bahwa factor kecerdasan emosi memberikan pengaruh atau kontribusi terhadap hasil belajar matematika sebesar $22,9 \%$, sedangkan $77,1 \%$ selebihnya dipengaruhi oleh faktor-faktor lain yang tidak diteliti dalam penelitian ini.

Goleman (2015: 42) yang menyatakan bahwa IQ hanya mempunyai peran sekitar $22,9 \%$ dalam menemukan hasil belajar individu, 77,1\% sisanya ditentukan oleh faktor-faktor lain termasuk emosi. Selain itu, Agus Efendi (2005: 183) menyatakan bahwa kecerdasan emosi diperlukan untuk berprestasi. Hal ini juga diperkuat dengan hasil penelitian yang dilakukan oleh Riheni Pamungkas (2013) mengenai pengaruh kecerdasan emosional terhadap hasil belajar matematika yang dilakukan pada peserta didik SD Negri301 Buttu Bila Kecamatan Lembang. Hasil analisis diperoleh koefisien korelasi sebesar 0,484 dan koefisien determinasi sebesar 0,229. Dari hasil penelitian terdahulu berarti terdapat pengaruh positif kecerdasan emosi terhadap hasil belajar matematika.

Mata pelajaran matematika merupakan mata pelajaran yang dianggap sulit oleh kebanyakan peserta didik. Hal ini dikarenakan masalah-masalah dalam matematika membutuhkan tahap penyelesaian yang sistematis. Matematika juga menuntut peserta didik untuk menggunakan logika dalam menyelesaikannya karena konsep-konsep dalam matematika bersifat abstrak.

Penyelesaikan masalah dalam mata pelajaran matematika diperlukan konsentrasi, kesabaran, dan ketelitian yang baik. Dalam mengelola konsentrasi, kesabaran, dan ketelitian dibutuhkan motivasi dan pengelolaan emosi yang kuat, sehingga peserta didik tidak musah putus asa dan menyerah ketika belum dapat menemukan jawaban penyelesaian yang tepat. Pada latar belakang diterangkan bahwa sikap, motivasi, ketekunan, kegigihan dan pengelolaan emosi diri dapat menghayati setiap materi pelajaran cenderung mengarah kepada kecerdasan emosi.

Kecerdasan emosi dapat memberikan sumbangan yang bermanfaat dalam mengelola emosi untuk dapat memusatkan perhatian untuk memahami materi pelajaran matematika, serta tetap optimis dan memotivasi diri dalam memperoleh hasil belajar matematika yang tinggi. Hal ini selaras dengan pendapat Conny R. Semiawan (2008: 12-13) yang mengungkapkan bahwa hasil belajar peserta didik tidak hanya ditentukan oleh faktor kognitif, namun juga faktor non-kognitif, termasuk kecerdasan emosi. Selain kecerdasan intelektual (IQ), kecerdasan emosi juga mempengaruhi hasil belajar peserta didik. Keseimbangan antara kecerdasan intelektual (IQ) dan kecerdasan emosi diperlukan untuk berkonsentrasi terhadap materi pelajaran 
yang dihadapi, mengatasi stres, atau kecemasan dalam persoalan tertentu.

\section{SIMPULAN}

Berdasarkan hasil penelitian dan pembahasan, maka kesimpulan yang dapat diambil adalah peserta didik yang memiliki kecerdasan emosi yang tinggi akan lebih terampil dalam menenangkan diri dan memusatkan perhatian dalam memahami materi pelajaran sehingga dalam penelitian dapat dikatakan bahwa terdapat pengaruh yang positif antara kecerdasan emosi terhadap hasil belajar matematika peserta didik SD Negeri 301 Buttu Bila sebesar 22,9\%. Hasil regresi untuk variabel kecerdasan emosi sebesar 0,229 , sehingga di peroleh persamaan regresi sederhana $Y=39,993+0,229 X$.

Mengingat ada pengaruh yang signifikan antara kecerdasan emosional dengan hasil belajar Matematika, maka peneliti menyarankan:(1) bagi peserta didik supaya lebih bersemangat untuk belajar, lebih tekun, dan pantang menyerah ketika menghadapi soal-soal Matematika mengingat Matematika merupakan salah satu mata pelajaran yang selalu ada pada setiap jenjang pendidikan dasar; (2) bagi guru hendaknya dapat menggunakan model-model pembelajaran yang mengandung pembentukan kepribadian yang kuat sehingga dapat meningkatkan kecerdasan emosional peserta didik; (3) bagi orang tua supaya dapat membiasakan anak dengan kegiatan membaca, mendongeng, selalu memberikan kesempatan anak untuk bercerita dan juga membimbing anak untuk menganalisis peristiwa yang ada di lingkungan sekitar.

\section{DAFTAR PUSTAKA}

Agustian, A.G. (2001). Rahasia Sukses Membangun Kecerdasan Emosi dan Spiritual, ESQ: Emotional Spiritual Quotient berdasarkan 6 Rukun Iman dan 5 Rukun Islam. Jakarta: Arga Wijaya Persada.

\footnotetext{
Efendi,A. (2005). RevolusiKecerdasanAbad21Kritik MI, EI, SQ, AQ, danSuccessfulIntelligence AtasIQ.Bandung: Alfabeta.
}

Goleman, D. (2015). Emosioanal Intelegense. Penerjemah: T. Hermaya. Jakarta. PT. Gramedia Pustaka Utama.

Hamzah B.U. (2008). Orientasi Baru dalam Psikologi Pembelajaran. Jakarta: PT Bumi Aksara.

Hudojo, H. (1990). Strategi Mengajar Belajar Matematika. Malang : IKIP Malang.

Nggermanto A. (2001). Quantum Quotient: Kecerdasan Quantum, Cara Praktis Melejitkan IQ, EQ, dan SQ yang Harmonis. Bandung: Nuansa.

Prihandoko, A.C. (2006). Memahami Konsep Matematika Secara Benar dan Menyajikannya dengan Menarik. Jakarta: Departemen Pendidikan Nasional.

Riheni, P. (2013). "Pengaruh Kecerdasan Emosional terhadap Hasil Belajar Matematika pada Peserta didik Kelas V Se-Kecamatan Prembun" Abstrak Hasil Penelitian UNS. Surakarta.

Sujana N. (1994). Cara Belajar Siswa Aktif dalam Proses Belajar Mengajar. Bandung: Sinar Bandung.

Sugiyono. (2008). Metode Penelitian Kuantitatif, Kualitatif dan $R \& D$. Bandung: Alfabeta.

Soedjadi. (2007). Masalah Kontekstual Sebagai Batu Sendi Matematika Sekolah. Surabaya: Pps UNESA.

Syah,M.(2013). PsikologiPen- didikan dengan Pedekatan Baru. Bandung: Rosdakarya.

Tajuddin. (2004). Komparasi Prestasi Belajar Matematika antara Metode Pemecahan Masalah dan Metode Ekspositori dalam Pembelajaran Pokok Bahasan Peluang pada Siswa Kelas II SMU Negeri I Takalar. Skripsi. Makassar: FMIPA UNM. 